\title{
P012. Body image role in medication-overuse headache associated with persistent depressive disorder
}

\author{
Maria Nicolodi, Vanessa Sandoval \\ From Abstracts from the 1st Joint ANIRCEF-SISC Congress \\ Rome, Italy. 29-31 October 2015
}

\section{Background}

Body image is a part of each person's self-esteem. Some evidence suggests that body image perception may have direct effects on one's feeling regarding quality of life $[1,2]$. Nonetheless, no research has examined the relationship of the impact of body image on medicationoveruse headache $(\mathrm{MOH})$ patients suffering also with persistent depressive disorder (PPD). Moreover, the role of body image is stressed in trials concerning mirror therapy $[3,4]$.

\section{Aim}

We propose that body image improvement can influence both pain perception and PPD in MOH sufferers.

\section{Materials and methods}

The present observational study started in March 2014. Inclusion criteria: 165 women, mean age $43.056 \pm 1.3 \mathrm{SD}$ diagnosed as $\mathrm{MOH}$ with the ICHD-III criteria and fulfilling DMS-V criteria for PPD. Controls were 106 healthy women, (mean age $43.7 \pm 1.59 \mathrm{SD}$ ). Women completed affective/cognitive measures of body image (BSQ-track and field). Zung and Hamilton tests were used for scoring depression, MIDAS for perceived quality of life. Each patient was videotaped. Raters, blind to health status, independently rated the attractiveness of the patients. Headache patients with depression reported lower selfesteem, a more negative body image perception than controls; all of them were rated as less attractive by observers when compared to the control group. The multivariate and uninvariate analyses of variance indicated that $\mathrm{MOH}$ patients with depression were less satisfied

* Correspondence: sicuteri@iol.it

Foundation Prevention and Therapy Primary Pain and Headache, Florence, Italy 


\section{References}

1. Morey $D$, Morey $L$ : The vulnerable body image of females with feelings of depression. J Res Pers 1991, 25:343-354.

2. Noles SW, Cash TF, Winstead BA: Body image, physical attractiveness, and depression. J Consult Clin Psychol 1985, 53:88-94

3. Osumi M, Imai R, Ueta K, Nobusako S, Morioka S: Negative body image associated with changes in the visual body appearance increases pain perception. PLoS One 2014, 9(9):e 107376.

4. Chan BL: Mirror therapy for phantom limb pain. Eng J Med 2007, 25(4):272-275.

doi:10.1186/1129-2377-16-S1-A111

Cite this article as: Nicolodi and Sandoval: P012. Body image role in medication-overuse headache associated with persistent depressive disorder. The Journal of Headache and Pain 2015 16(Suppl 1):A111.

\section{Submit your manuscript to a SpringerOpen ${ }^{\circ}$ journal and benefit from:}

- Convenient online submission

- Rigorous peer review

- Immediate publication on acceptance

- Open access: articles freely available online

- High visibility within the field

- Retaining the copyright to your article 